\title{
Local Environmental Policy in a Federal System: An Overview
}

\section{Kathleen Segerson}

\begin{abstract}
A number of issues arise when considering the positive and normative implications of local environmental policy making. This paper provides an overview of some of the issues and implications. These vary depending on whether local jurisdictions are charged with determining the stringency of policies or instead stringency is determined at a higher level of government and the local role focuses on implementation and the design of cost-effective measures for achieving the required goals. Key issues include both physical and economic spillovers across jurisdictions, and the extent to which stringency can be differentiated based on local conditions or preferences.
\end{abstract}

Key Words/Phrases: Environmental Federalism, Interjurisdictional Spillovers, Local Policy-making

\section{Introduction}

Although much of the debate over environmental policy focuses on national or international action (or inaction), in practice policy decisions at the local level are often equally or perhaps even more important in determining the individual choices that ultimately lead to environmental protection or degradation. ${ }^{1}$ It has long been recognized that local governments have primary jurisdiction over most land use regulations, which they typically exercise through zoning regulations (Fischel 2000). However, subnational environmental policies now span a broad array of contexts beyond land use, including local or regional carbon taxes or cap-and-trade systems, ${ }^{2}$ state or municipal plastic

\footnotetext{
Department of Economics, University of Connecticut, Storrs, CT 06269

Email: kathleen.segerson@uconn.edu

This article is based on an opening keynote address given at the Northeast Agricultural and Resource Economics Association (NAREA) workshop on "Environmental Regulation and Innovation in Local Communities" held in Portsmouth, NH, on June 11, 2019.

1 In fact, although U.S. federal funding for environmental protection has been under attack, state budgets have been increasing. See a recent report by the Environmental Council of States: https:// www.ecos.org/wp-content/uploads/2017/03/Budget-Report-FINAL-3_15_17-Final-4.pdf.

2 Prominent examples of regional cap-and-trade markets include California's RECLAIM program for nitrogen and sulfur oxides (http://www.aqmd.gov/home/programs/business/about-reclaim) and the Regional Greenhouse Gas Initiative (RGGI) for carbon emissions (https://www.rggi.org/). For other examples of carbon pricing initiatives at both the national and subnational levels, see World Bank and Ecofys (2018).
}

Agricultural and Resource Economics Review 49/2 (August 2020) 196-208

(C) The Author(s) 2020. This is an Open Access article, distributed under the terms of the Creative

Commons Attribution licence (http://creativecommons.org/licenses/by/4.0/), which permits unrestricted re-use, distribution, and reproduction in any medium, provided the original work is properly cited. 
bag bans, ${ }^{3}$ state-level auto emissions standards, ${ }^{4}$ and state-level bans or restrictions on hydraulic fracturing ("fracking"). ${ }^{5}$ As these examples illustrate, subnational actions can involve setting local standards, regulations, or taxes, but they can also include designing implementation plans for policies set at the national level and/or monitoring and enforcing federal standards (e.g., Oates 2002; Chang, Sigman, and Traub 2014; Lin 2010). Examples include the State Implementation Plans under the U.S. Clean Air $\mathrm{Act}^{6}$ and the development of Total Maximum Daily Load (TMDL) plans under the U.S. Clean Water Act. ${ }^{7}$ Thus, national and subnational units of government play a shared role in addressing environmental issues, and local policies can be substitutes for, or complements to, policies implemented at higher levels (Shobe and Burtraw 2012; Datt and Mehra 2016).

Moreover, decision making at various levels is often interdependent, as when one level of government enacts policies specifically designed to enhance or undermine policies set at another level (Shobe and Burtraw 2012; Williams 2012; Chang, Sigman, and Traub 2014; Shobe 2020). For example, a state might seek to impose regulations (such as auto emissions standards) that are more stringent than those set at the federal level when it feels federal regulations are not sufficient for that state. In this case, the federal standards act as minimum standards, with states having the option to go beyond those minimums. Alternatively, a state that feels a federal regulation or other policy is too restrictive could seek to offset the impacts through other policies designed to lower the regulatory burden on impacted firms within that state. For example, if a federal carbon tax were imposed, a state could adopt offsetting subsidies to coal producers within that state to help increase the industry's profitability and thereby reduce concerns about a negative impact of the tax (Shobe 2020). State-level responses of these types imply a degree of strategic interaction between various levels of government that have a role in environmental policy design.

For all of these reasons it is important to understand both the rationale for and the implications of policy-related choices made at the local level. A large body of literature on environmental federalism seeks to address these issues. Shobe and Burtraw (2012) describe environmental federalism as "the study of the normative and positive consequences of the shared role of national

\footnotetext{
3 For examples, see https://www.ncsl.org/research/environment-and-natural-resources/ plastic-bag-legislation.aspx.

4 For example, under the U.S. Clean Air Act, California has been granted the ability to set emissions standards for motor vehicles that are more stringent than the federal standards. See https://www.epa.gov/state-and-local-transportation/vehicle-emissions-california-waivers-andauthorizations.

5 To date, only a few jurisdictions have implemented bans in the United States (see https:// insideclimatenews.org/news/20150120/map-fracking-boom-state-state).

6 See https://www.epa.gov/air-quality-implementation-plans/sip-requirements-clean-air-act.

7 See https://www.epa.gov/tmdl/overview-total-maximum-daily-loads-tmdls\#3.
} 
and subnational units of government in controlling environmental problems." Useful surveys of this literature include Oates (2002); Dijkstra and Fredriksson (2010); and Shobe (2020). This paper provides an overview of some of the issues that can/do arise when policy is made at the local level and thereby provides a broad context in which the papers from the NAREA workshop published in this volume can be placed.

\section{Motivations for Local Environmental Policy}

As noted above, there are many examples of local or subnational governments enacting environmental policies "on their own" (as opposed to in response to a mandate from a higher level regulatory authority) or adopting policies that are more stringent than required by federal policy. A fundamental question is why they do this. In the case of a local public good or bad, one answer is simply that local governments are enacting policies that benefit residents within those jurisdictions. Land use and local drinking water regulations are examples. However, when the benefits of an action accrue to individuals outside that jurisdiction (see further discussion below), it is less clear what motivates local communities or subnational governments to act. Again, it is possible that they are simply reflecting the will or preferences of local residents, but this does not address the question of why local residents are willing to incur the costs of actions that benefit people outside their local communities. Examples include local carbon taxes and local laws prohibiting or taxing plastic bags.

One explanation is that local actions might generate multiple benefits (cobenefits), some of which are realized outside the jurisdiction but others that are more local. For example, bans on fracking are often based on a goal of reducing the use of fossil fuels and the associated carbon emissions but can also address concerns about the impacts of fracking on local water quality and/or land subsidence (e.g., Cotton 2015). Similarly, local policies to promote renewable energy sources can reduce greenhouse gas emissions but also generate local benefits, such as jobs or improvements in local air quality (Harrison 2013). In such cases, the good being valued by the local jurisdiction can be viewed as an impure public good, i.e., a good that generates both private benefits to the jurisdiction itself as well as public benefits to others outside the jurisdiction. ${ }^{8}$ If the private or co-benefit that is realized locally is sufficiently large, it might be seen as justifying local action regardless of any benefits realized beyond its borders.

In addition, even if a centralized government acts to regulate or tax emissions, a local government may choose to impose more stringent regulations or an

\footnotetext{
8 This is analogous to impure public consumption goods, i.e., goods such as green electricity that generate private benefits for the purchaser (consumer) as well as public benefits for others. See, for example, Kotchen (2006).
} 
emission tax of its own. This can occur, for example, if the federal policy is based on an average across all jurisdictions and local marginal damages from emissions within that local jurisdiction are relatively high. Moreover, the incentive for local jurisdictions to impose local policies even in the presence of federal policies is stronger under emissions taxes than under emissions standards when federal taxes are not returned to jurisdictions in a lump sum way (Williams 2012).

The above motivations for local action presume that those actions would lead to some localized environmental benefits. Alternatively, actions by local jurisdictions might simply reflect the values held by a sufficiently large group of residents within that jurisdiction, which generate support for environmentalism at the local (as well as higher) levels and can lead to a willingness to accept policies that impose costs (such as higher prices) in support of broader public goals (Stern et al. 1999). These values might reflect "green" or altruistic preferences (e.g., van't Veld 2020), or a sense of moral obligation or even guilt (Onwezen, Antonides, and Bartels 2013).

Finally, environmental policies based on taxes or fees can also be a means of raising revenue for states or even local jurisdictions (see, for example, Harrison 2013; Alexeev, Good, and Krutilla 2016). Examples include not only local emissions taxes but also congestion pricing or tolls designed to reduce traffic and the associated pollution. The fact that environmental taxes/fees can simultaneously improve environmental outcomes and raise revenue has been termed a "double dividend" (Goulder 1995; Bovenberg 2002). In the absence of any environmental benefit, environmental taxes would not typically be the most efficient way to raise revenue for governments, because they tend to be narrowly targeted and would hence generate a larger deadweight loss than other, more broadly based taxes. However, when their environmental benefits are considered, the case for using environmental taxes to raise revenue is strengthened.

Of course, the jurisdictional level that imposes the tax also receives the revenue. This implies that a local jurisdiction would benefit from the revenue-raising property of an environmental tax if it is imposed locally but not (necessarily) if it is imposed by the central government. ${ }^{9}$ Similarly, the revenue raised by an auction-based state or regional cap-and-trade program would go to that region, ${ }^{10}$ while that revenue would go to the federal government under a federally run program. This reflects a difference in the implied "ownership" of the resource or property rights (Shobe and Burtraw 2012). For example, a federal tax or cap-and-trade policy implicitly assumes the central government owns and has the right to give away or "sell"

\footnotetext{
9 The net impact of a federal tax depends, of course, on how the tax revenue is used and the extent to which either the revenue itself or the services provided by that revenue are distributed.

10 For example, the states participating in the Regional Greenhouse Gas Initiative have collected nearly $\$ 3.5$ billion in revenue from auctions since the first auction back in 2008 . See https://www. rggi.org/auctions/auction-results.
} 
pollution rights, while under a state policy ownership implicitly lies with the state.

One implication of state or local-level action is that it can lead to a patchwork of policies that vary across jurisdictions. Although there are conditions under which that variation will be efficient (see discussion below), it can result in greater uncertainty and higher costs. For example, producers seeking to operate in multiple jurisdictions will need to be aware of and adapt to a potentially wide range of local laws and regulations. This might be especially costly when there are economies of scale in production. The state-level auto emissions standards imposed by the State of California are a case in point. In fact, some auto manufacturers have agreed to meet the higher California standards across all U.S. sales simply to avoid the need to tailor production standards and specifications to individual states. ${ }^{11}$ In addition, if states or local jurisdictions take the lead in enacting policies, this might spur federal action (Fisher 2012; Brunell and Cease 2019). However, an existing patchwork of policies will make federal actions to harmonize policies more difficult, especially if state-level policies have become entrenched (Shobe and Burtraw 2012).

\section{Environmental Spillovers and Heterogeneity}

Even if a state or local jurisdiction has the incentive or motivation to adopt policies to protect the environment, one could ask whether they should be allowed to do so, or whether instead policy should be set at a higher level. More specifically, what are the implications (positive and negative) of vesting local governments with different types of decision-making authority, and given these implications, should local governments have this control? Not surprisingly, the answers to these questions vary across contexts. Nonetheless, two fundamental factors play a dominant role: interjurisdictional environmental spillovers and spatial heterogeneity across localities (which is a key theme of papers in this volume).

While the discussion about local motivation above highlighted the role of the benefits within a jurisdiction, the issue of interjurisdictional spillovers focuses on the role of benefits realized outside the jurisdiction. The extent of interjurisdictional spillovers depends on the specific pollutant or environmental impact of concern (Oates 2002). As noted above, some pollutants, such as $\mathrm{CO}_{2}$ or ozone-depleting chemicals, can be viewed as global public bads, where the benefits of unilateral actions by individual localities accrue overwhelmingly to individuals outside those localities. Absent other more localized co-benefits, local jurisdictions may have little incentive to take unilateral action. Conversely, some environmental problems can be viewed as

\footnotetext{
11 See https://www.gov.ca.gov/2019/07/25/california-and-major-automakers-reach-groundbreakingframework-agreement-on-clean-emission-standards/.
} 
primarily local, with local actions having little impact outside that locality. Examples include waste disposal and degradation of local drinking water quality. In between these two ends of the spectrum are pollutants that impact the locality in which they originate as well as neighboring jurisdictions. These include sulfur dioxide emissions, ground-level ozone, and water pollution in interjurisdictional lakes and rivers.

The presence of interjurisdictional spillovers or externalities is often cited as a strong rationale for policy making at higher levels (Oates 2002; Banzhaf and Chupp 2012; Shobe 2020). The validity of this argument depends on the specific nature of the policy decisions. For example, interjurisdictional spillovers suggest that local jurisdictions cannot be relied upon to set efficient environmental standards, regulations, or even tax rates, since even if they act unilaterally, they will not (necessarily) consider the full extent of the impacts of their policy choices on other jurisdictions. However, this does not necessarily mean that they should not have a say in the implementation of targets within their jurisdictions. For example, even if overall emissions limits for a given jurisdiction are set at a higher level (to account for spillovers), the jurisdiction could play an important role in determining the means by which those limits would be met, i.e., in designing the implementation of policies imposed from above. ${ }^{12}$ For example, the Clean Power Plan that was proposed by the Obama Administration gave states considerable flexibility in deciding how they would meet required reductions in carbon emissions. ${ }^{13}$ Similarly, if central funds are allocated to a jurisdiction to improve water quality or promote conservation (see further discussion below), the local jurisdiction might be in a better position than the central government to determine how those funds should be spent to maximize their effectiveness.

One key reason for relying on local jurisdictions to decide on policy implementation (or, in the absence of spillovers, the regulatory targets themselves) is heterogeneity across jurisdictions (Banzhaf and Chupp 2012; Shobe and Burtraw 2012). This heterogeneity could reflect differences in preferences within the jurisdiction, in levels or type of development, or in environmental characteristics (e.g., coastal vs. inland jurisdictions). Heterogeneity implies that "one size" does not fit all, and local control allows policies or implementation strategies to be tailored to local preferences and conditions. In particular, the local benefits and costs of alternative approaches will depend on preferences and conditions within that jurisdiction, implying that an approach that is best for one jurisdiction may not be best for another. On the other hand, heterogeneity can also provide a

12 However, Lin (2010) argues that conditions exist under which the opposite would be true, i.e., it would be more efficient to have standards set at the local level with federal regulators then determining the means by which those standards would be met. This can arise, for example, when state-level enforcement and verification are imperfect.

13 See https://archive.epa.gov/epa/cleanpowerplan/fact-sheet-overview-clean-power-plan.html. 
rationale for implementation or design of policy at a higher level. For example, when designing a cap-and-trade policy, having a single larger market for trades, i.e., one that spans multiple jurisdictions, will allow the policy to achieve greater cost savings when cost heterogeneity across jurisdictions is significant.

The discussion above focuses on the implications of local-level decision making as a substitute for, or complement to, actions taken by a central government. As noted, this discussion is often cast as a trade-off between interjurisdictional spillovers (favoring centralized control) and heterogeneity (often, but not exclusively, favoring local control). Banzhaf and Chupp (2012) characterize the problem as a choice between two different types of "errors" in setting prices: local control systematically sets prices (or the corresponding quantities) too low because of failure to consider interjurisdictional externalities, while uniform centralized policy averages under- and over-pricing because of its inability to tailor prices to local conditions. ${ }^{14}$ The spillovers of interest here reflect physical movement of pollutants or the resulting contamination from one jurisdiction to another, either because of the transboundary nature of some pollutants (where, for example, air currents or water flows transport pollutants across jurisdictional boundaries) or, in the case of product-related externalities, because consumers transport polluting products (e.g., automobiles) from one jurisdiction to another. In either case, the spillover stems directly from the pollution itself. However, local actions can also lead to economic spillovers when jurisdictions are connected not only physically but through flows of goods/services and factors of production as well. These spillovers have also raised concerns about impacts of actions taken at a local level.

\section{Economic Spillovers: Leakage and Interjurisdictional Competition}

The interconnectedness of the economies of local jurisdictions implies that actions taken unilaterally in one jurisdiction can lead to a shift in production or consumption from that jurisdiction to other jurisdictions if the resources (capital, labor, and materials) needed for production are mobile or if consumers can substitute toward goods/services from other jurisdictions. This can give rise to leakage and/or interjurisdictional competition, both of which have received considerable attention in the economic literature on local environmental policy making.

Although the term leakage has been used in a wide variety of contexts, in the context of interest here it refers generally to an outcome where a unilateral environmental policy implemented within one jurisdiction causes an unintended response (such as increased production) in another jurisdiction that partially or even fully offsets the effectiveness of the policy. For example,

\footnotetext{
14 Banzhaf and Chupp (2012) show that the relative costs of these two types of errors will depend on the convexity of marginal costs.
} 
if a ban on phosphorous detergents in one local jurisdiction causes at least some people to travel to neighboring jurisdictions to buy those detergents, the ban will be less effective than otherwise (Cohen and Keiser 2017). Similarly, if a unilateral carbon tax or cap-and-trade policy within one jurisdiction (or region) causes production to shift elsewhere to avoid the associated costs, the reduction in emissions in that jurisdiction will be offset by the extent of the increase in production and associated emissions in other places (e.g., Fell and Maniloff 2018).

In addition, when resources are mobile, concerns have been raised that local jurisdictions might want to compete for those resources by setting lax local environmental regulations, thereby resulting in a "race to the bottom" in terms of environmental quality. A large literature exists on this type of interjurisdictional competition for resources (Oates 2002; Dijkstra and Fredriksson 2010), focusing primarily on stationary pollutants generated by production processes (rather than pollutants that cross boundaries or stem from consumption or use of a product, such as an automobile). Both the theoretical and empirical results on this are mixed. For example, the early theoretical literature (Oates and Schwab 1988), which assumed perfectly competitive jurisdictions and no pollution spillovers, found that Tiebout-like competition would lead local jurisdictions to make efficient decisions about local environmental policies as they sought to balance the local benefits and costs of more stringent standards. However, relaxing these assumptions by, for example, allowing strategic interaction among jurisdictions can lead to standards that are too stringent or too lenient, depending on the policy instrument used by the local government, the timing of the moves by regulators and firms, and the ownership of the mobile resource (Dijkstra and Fredriksson 2010).

The empirical literature on whether local policy making causes a race to the bottom is also mixed. For example, although there is evidence of strategic interaction and free riding among states, the evidence also suggests that the devolution of regulatory authority does not necessarily lead to a reduction in environmental quality (Dijkstra and Fredriksson 2010). Nonetheless, there are clearly some contexts, such as climate change, where devolution to subnational governments is very unlikely to yield outcomes that are efficient, due primarily to the public good nature of reductions in greenhouse gas emissions (Shobe and Burtraw 2012; Harrison 2013).

\section{Local Experimentation}

One purported advantage of policy making at the local level is that it provides an opportunity for experimentation that can generate a better understanding of what works and what does not, and it can reveal potential unanticipated consequences of policies (Treisman 2007; Shobe and Burtraw 2012; Garzarelli and Keeton 2018). The knowledge gained through local experimentation can then be diffused either horizontally (to other local 
jurisdictions) or vertically (to a higher level of government, such as the state or federal level) so that effective policies can be scaled up.

Although local experimentation can be useful, there are several concerns about relying on it for learning about policy impacts (Shobe and Burtraw 2012; Shobe 2020). For example, since knowledge is a public good, local jurisdictions cannot be expected to supply the efficient amount of it. In other words, local jurisdictions do not face efficient incentives to experiment for the purposes of generating new understanding that benefits other jurisdictions, and could instead free ride on the experimentation efforts of others. Perhaps more important, however, is the challenge of identifying causal policy impacts by simply observing success or failure in one jurisdiction. Causal inference requires a well-designed experiment that allows comparison with a valid counterfactual, and most local policy initiatives are not designed with that in mind. Thus, observing that a desirable outcome followed the imposition of a local policy in one jurisdiction does not necessarily mean that the policy caused that outcome, even in that jurisdiction. Moreover, even if it did, heterogeneity across jurisdictions and pollutants makes it difficult to generalize results to other contexts. In fact, as noted above, the same heterogeneity that provides a justification for localized decision making, i.e., that prevents a "one size fits all" approach from being efficient, suggests that learning from local experimentation might be limited.

\section{The Role of Funding}

The focus thus far has been primarily on policy decisions related to setting and implementing environmental targets, through, for example, standards, regulations, and/or taxes and fees. However, the question of which level of government decides on needed environmental actions or policies is separate from the question of which level pays the associated costs. At a minimum, these costs include the administrative costs associated with policy implementation. In addition, depending on the policy design, they can also include costs of the pollution control efforts themselves. Although private polluters bear those costs under regulatory or tax approaches, under subsidy (or cost-sharing) approaches funding to finance those programs must come from public funds (e.g., tax revenue). Public funding is also needed when the policies require pollution control at facilities owned or operated by public agencies, such as publicly owned wastewater treatment plants.

The revenue needed to fund local actions that are not centrally mandated would typically come from local sources (e.g., local taxes or bonds). However, even if a federal government mandates that lower levels of government take certain actions (e.g., implement certain regulations), it will not necessarily provide the funding necessary for the state or local government to comply with that mandate. These so-called "unfunded mandates" can create significant burdens for state and local governments (e.g., Ross 2018). For example, the U.S. Chamber of Commerce estimated that between 2004 and 
2015 new regulations and requirements by the U.S. Environmental Protection Agency (EPA) imposed over $\$ 100$ billion in additional costs on states (Kovacs, Johnson, and Holman 2016). Alternatively, central governments can directly fund or incentivize environmental actions taken at the local level through intergovernmental grants (Fisher 2012; Datt and Mehra 2016). A prominent example is the U.S. Clean Water Act's grants to municipal wastewater treatment plants (Keiser and Shapiro 2019). The extent to which intergovernmental grants come with restrictions or conditions regarding their use will impact the flexibility that local governments have in using those funds (e.g., Garzarelli and Keeton 2018). This will, in turn, affect the extent to which local governments can tailor that use to preferences and conditions within their jurisdictions.

There are reasons both for and against funding the public costs of environmental initiatives using federal rather than state or local funding. First, the literature on optimal taxation suggests that, ceteris paribus, federal governments would typically be able to raise revenue more efficiently than state or local governments. ${ }^{15}$ Given substitutability and/or mobility of resources across subnational jurisdictional lines, unilateral state or local taxes can generate larger deadweight losses as individuals and firms modify decisions in an effort to reduce their tax burdens. Second, requiring the central government to fund its mandates can reduce the potential for "overregulation" that could arise if central governments perceive that policies would generate benefits but do not accept responsibility for (and hence do not fully consider) the associated costs (Miceli and Segerson 1999). In fact, concern for this type of overregulation was one impetus behind the Unfunded Mandate Reform Act (e.g., Gullo 2004), which was designed to limit the federal government's use of unfunded mandates. Third, to the extent that federal action is in response to interjurisdictional externalities, federal funding can help compensate a jurisdiction for benefits its actions generate for other jurisdictions. The prospect of receiving compensation for the costs of generating those external benefits would provide the jurisdiction with an incentive to consider them in setting local policies. Finally, federal funding allows for a cross-subsidization of the costs of environmental protection ${ }^{16}$ so that wealthier jurisdictions can help offset the cost for poorer jurisdictions and help ensure comparable protection regardless of income or race, which is a key goal of environmental justice (Banzhaf, Ma, and Timmins 2019).

\footnotetext{
15 When resources are mobile across jurisdictions, taxation within a given jurisdiction generates a "horizontal" fiscal externality on other jurisdictions. However, in a federal system when multiple levels of government have taxation authority, local taxation can also create a "vertical" fiscal externality. For discussions of the implications of this for optimal taxation, see, for example, Sobel (1997) and Hoyt (2001).

16 As noted above, this cross-subsidization can also occur under a federal tax policy where revenues are not redistributed to states in a neutral manner.
} 
Although these are strong arguments in favor of centralized funding, there are also arguments that support funding initiatives through state or local sources of revenue. A key reason is to provide those jurisdictions with an incentive to meet environmental protection goals in the least-cost way. When funding comes from outside the jurisdiction, it can create a moral hazard problem, especially if the funds are primarily based on costs incurred by the jurisdiction, i.e., if they are designed to provide "cost-recovery" (Miceli and Segerson 1999). The moral hazard problem can be reduced through the use of cost-sharing or matching grants that require at least part of the funding to come from local sources. Requiring local funding could also be viewed as being consistent with the polluter-pays principle, at least to the extent that polluting parties contribute to the local tax revenues used to fund the environmental initiatives.

\section{Conclusion}

A number of issues arise when considering the positive and normative implications of local environmental policy making. Importantly, those implications can be quite different when local jurisdictions have the ability (and responsibility) to determine the stringency of policies than when stringency is determined at a higher level of government and the local role focuses on implementation and the design of cost-effective measures for achieving the required goals. The presence of both physical and economic spillovers across jurisdictions favors setting policy stringency at a higher level, especially if stringency can be differentiated based on local conditions or preferences. On the other hand, if stringency cannot be differentiated, then heterogeneity in local conditions or preferences is an argument in favor of local control. In addition, even if stringency can be differentiated, heterogeneity suggests that local jurisdictions can play an important role in determining how targets will be met or available funds will be spent.

Despite the strong arguments in favor of federal leadership and action to address environmental concerns, it is clear that many local jurisdictions feel compelled to act on their own, either as a complement to or a substitute for federal action (or inaction). In many cases, the motivation for this appears to go beyond the local benefits those actions generate and reflects instead a broader interest of some jurisdictions in promoting environmentalism even when it entails net costs for people in those jurisdictions. These local initiatives can either replace or spur federal action. Ultimately, the interplay between the local and federal levels will lead to a portfolio of policy provisions. The extent to which that portfolio is integrated and/or coordinated (both horizontally and vertically) will determine both its effectiveness and its efficiency.

\section{Funding Statement}

This research received no specific grant from any funding agency, in either the commercial or not-for-profit sectors. 


\section{References}

Alexeev, A., D.H. Good, and K. Krutilla. 2016. "Environmental Taxation and the Double Dividend in Decentralized Jurisdictions." Ecological Economics 122: 90-100.

Banzhaf, H.S., and B.A. Chupp. 2012. "Fiscal Federalism and Interjurisdictional Externalities: New Results and an Application to US Air Pollution." Journal of Public Economics 96: 449-464.

Banzhaf, S., L. Ma, and C. Timmins. 2019. "Environmental Justice: The Economics of Race, Place, and Pollution." Journal of Economic Perspectives 33(1): 185-208.

Bovenberg, A. L. 2002. "Green Tax Reforms and the Double Dividend: An Updated Reader's Guide." In. L.H. Goulder, ed., Environmental Policy Making in Economies with Prior Tax Distortions. Cheltenham, U.K. and Northampton, MA: Edward Elgar Publishing.

Brunell, T.L., and B. Cease. 2019. "How Do State-Level Environmental Policies Impact the Voting Behavior of National Legislators?" Social Science Quarterly 100(1): 289-306.

Chang, H.F., H. Sigman, and L.G. Traub. 2014. "Endogenous Decentralization in Federal Environmental Policies." International Review of Law and Economics 37: 39-50.

Cohen, A., and D.A. Keiser. 2017. "The Effectiveness of Incomplete and Overlapping Pollution Regulation: Evidence from Bans on Phosphate in Automatic Dishwasher Detergent." Journal of Public Economics 150: 53-74.

Cotton, M. 2015. "Stakeholder Perspectives on Shale Gas Fracking: A Q-method Study of Environmental Discourses." Environmental Planning A 47:1944-1962.

Datt, D., and M.K. Mehra. 2016. "Environmental Policy in a Federation with Special-Interest Politics and Inter-governmental Grants." Environmental and Resource Economics 64(4): 575-595.

Dijkstra, B.R., and P.G. Fredriksson. 2010. "Regulatory Environmental Federalism." Annual Review of Resource Economics 2: 319-339.

Fell, H., and P. Maniloff. 2018. "Leakage in Regional Environmental Policy: The Case of the Regional Greenhouse Gas Initiative." Journal of Environmental Economics and Management 87: 1-23.

Fischel, W. 2000. "Zoning and Land Use Regulation." In B. Bouckaert and G. DeGeest, Encyclopedia of Law and Economics: Volume II. Cheltenham, UK: Edward Elgar Publishing, pp. 403-442.

Fisher, D.R. 2012. "Understanding the Relationship between Subnational and National Climate Change Politics in the United States: Toward a Theory of Boomerang Federalism." Environmental Planning C: Government and Policy 31: 769-784.

Garzarelli, G., and L. Keeton. 2018. "Laboratory Federalism and Intergovernmental Grants." Journal of Institutional Economics 14(5): 949-974.

Goulder, L.H. 1995. "Environmental Taxation and the Double Dividend: A Reader's Guide." International Tax and Public Finance 2(2): 157-183.

Gullo, T. 2004. "History and Evaluation of the Unfunded Mandates Reform Act." National Tax Journal 57(3): 559-570.

Harrison, K. 2013. "Federalism and Climate Policy Innovation: A Critical Reassessment." Canadian Public Policy 39: S95-S108.

Hoyt, W.H. 2001. "Tax Policy Coordination, Vertical Externalities, and Optimal Taxation in a System of Hierarchical Governments." Journal of Urban Economics 50(3): 491-516.

Keiser, D.A., and J.S. Shapiro. 2019. "Consequences of the Clean Water Act and the Demand for Water Quality." Quarterly Journal of Economics 134(1): 349-396.

Kotchen, M.J. 2006. "Green Markets and Private Provision of Public Goods." Journal of Political Economy 114(4): 816-834.

Kovacs, W.L., J.M. Johnson, and K.W. Holman. 2016. The Growing Burden of Unfunded EPA Mandates on States. U.S. Chamber of Commerce, Technology and Regulatory Affairs Division (https://www.uschamber.com/sites/default/files/documents/files/022879_etra_ epa_coercive_federalism_report_fin.pdf). 
Lin, C-Y.C. 2010. "How Should Standards Be Set and Met? On the Allocation of Regulatory Power in a Federal System." The B.E. Journal of Economic Analysis and Policy 10(1), Article 51.

Miceli, T.J., and K. Segerson. 1999. "Threshold Rules for Funding Environmental Mandates: Accountability and the Unfunded Mandate Reform Act." Land Economics 75(3): 375-389.

Oates, W.E. 2002. "A Reconsideration of Environmental Federalism." In J.A. List and A. deZeeuw, eds. Recent Advances in Environmental Economics, Cheltenham, U.K. and Northampton, MA: Edward Elgar Publishing.

Oates, W.E., and R.M. Schwab. 1988. "Economic Competition among Jurisdictions: Efficiency Enhancing or Distortion Inducing?" Journal of Public Economics 35(3): 333-354.

Onwezen, M.C., G. Antonides, and J. Bartels. 2013. "The Norm Activation Model: An Exploration of the Functions of Anticipated Pride and Guilt in Pro-environmental Behaviour." Journal of Economic Psychology 39:141-153.

Ross, J.M. 2018. "Unfunded Mandates and Fiscal Structure: Empirical Evidence from a Synthetic Control Model." Public Administration Review 78(1): 92-103.

Shobe, W. 2020. "Emerging Issues in Decentralized Resource Governance: Environmental Federalism, Spillovers and Linked Socio-Ecological Systems." Annual Review of Resource Economics 12. Doi: 10.1146/annurev-resource-110319-114535.

Shobe, W.M., and D. Burtraw. 2012. "Rethinking Environmental Federalism in a Warming World." Climate Change Economics 3(4): 1-33.

Sobel, R.S. 1997. "Optimal Taxation in a Federal System of Governments." Southern Economic Journal 64(2): 468-485.

Stern, P.C., T. Dietz, T. Abel, G.S. Guagnano, and L. Kalof. 1999. "A Value-Belief-Norm Theory of Support for Social Movements: The Case of Environmentalism." Human Ecology Review 6(2): 81-97.

Treisman, D. 2007. The Architecture of Government: Rethinking Political Decentralization. Cambridge: Cambridge University Press.

van't Veld, K. 2020. "Eco-Labels: Modeling the Consumer Side." Annual Review of Resource Economics 12. doi: 10.1146/annurev-resource-110319-115158.

Williams III, R.C. 2012. “Growing State-Federal Conflicts in Environmental Policy: The Role of Market-based Regulation." Journal of Public Economics 96: 1092-1099.

World Bank and Ecofys. 2018. State and Trends of Carbon Pricing 2018 (May). Washington, DC: World Bank. doi: 10.1596/978-1-4648-1292-7. 